\title{
EFFECT OF INTRAMUSCULAR FAT CONTENT ON PHYSICAL-CHEMICAL PARAMETERS OF PORK FROM MANGALITSA AND THEIR CROSSBREEDS
}

\author{
Petra Lípová, Ondrej Debrecéni, Ondřej Bučko, Klára Vavrišínová
}

\begin{abstract}
The aim of study was to evaluate the effect of intramuscular fat content on physical parameters and proximate composition in musculus longissimus dorsi (MLD) from Mangalitsa breed and Slovak Large White x Mangalitsa crossbreed. In the study, sixteen pigs of Mangalitsa and twenty-two pigs of Slovak Large White x Mangalitsa crossbreed were used. The pigs were reared under intensive condition and all animals were fed ad libitum with complete fattening feed mixture. The fattening period started from $30 \mathrm{~kg}$ of live weight. Then the pigs were slaughtered at $100 \mathrm{~kg}$ of live weight. Chemical analysis showed that MLD from Mangalitsa had lower protein content, higher moisture content $(p<0.05)$ and higher content of intramuscular fat compared to Slovak Large White x Mangalitsa crossbreed. As regarding the cholesterol content in MLD, no significant differences were found between genotypes, but the cholesterol content was higher in MLD from Mangalitsa than in MLD from crossbreeds. The MLD from Mangalitsa exhibited lower CIE L* $(p<0.01)$ and CIE $\mathrm{b}^{*}(p<0.01)$ values 45 min post mortem compared to crossbreeds. Colour parameters increased after 7 days post mortem, which is normal due to the maturing process of the meat. Then the CIE $\mathrm{L}^{*}$ value was lower in MLD from Mangalitsa $(p<0.01)$, but CIE a* value was higher in relation to crossbreeds $(p<0.05)$. As regards the Warner-Bratzler shear force, the meat from Mangalitsa was tenderer than in crossbreeds $(p<0.05)$. Intramuscular fat in the meat positively correlated with colour parameter CIE a* $(r=0.324 ; p<0.05)$ as well as cholesterol content $(r=0,656 ; p<0.001)$. In contrast in the study was found negative correlations between intramuscular fat in meat with moisture content $(r=-0.399 ; p<0.05)$ and protein content $(r=-0.812 ; p<0.001)$. It can be concluded that the percentage of intramuscular fat significantly influenced the physical and the chemical parameters of pork. The meat from Mangalitsa is more suitable for production of special meat products (fermented and smoked).
\end{abstract}

Keywords: crossbreeds; intramuscular fat; Mangalitsa; musculus longissimus dorsi; pork

\section{INTRODUCTION}

Meat quality is evaluated according to quality parameters such as $\mathrm{pH}$, colour or intramuscular fat content. Meat colour is one of the main quality properties which influence consumer's acceptance, but also reflects the quality of meat (Estévez, Morcuende and Cava, 2003; Alonso et al., 2009). Within the qualitative parameters of meat, evaluating percentage of intramuscular fat seems to be the best way to separate indigenous pigs from commercial breeds (Pugliese and Sirtori, 2012), because it is usually observed that intramuscular fat content in important cuts of pork is less than $1.5 \%$ in pig meat breeds (Hamill et al., 2012). Jeong et al. (2010) indicated that intramuscular fat content is important factor that contribute to eating quality and it is influenced by genotype, gender, age and diet. Some reports indicate that when intramuscular fat content increases from $1 \%$ to $3 \%$, the qualitative parameters increase at high rate. However as intramuscular fat content increase from $3 \%$ to
$6 \%$, the qualitative traits also improve, but at the lower levels.

The indigenous breeds such as Iberian and Mangalitsa are known to have desirable quality properties of meat that could be of interest to farm, giving the possibility to produce unique high-quality meat products. These indigenous breeds have a high intramuscular fat content (Straadt, Aaslyng and Bertram, 2013). Mangalitsa is one of the most popular rustic pig breeds in Europe, because the meat has excellent properties, such as taste, marbling and low cholesterol content (Pârvu et al., 2012). This breed is also characterized by dark colour of meat, robust constitution and slower growth rate with higher content of fat in carcass $(65 \%-70 \%)$ and reduced content of meat $(30 \%-35 \%)$ in carcass compared to commercial breeds (Egerszegi et al., 2003; Stanišić et al., 2013).

In the intensive pig production, the most common crossbreeding program is to use breeds such as Large White, Duroc, Pietran, to improve some production parameters as 
well as qualitative traits in meat (Alonso et al., 2015). In the last several decades, pigs have been crossed for the rapid production of lean meat and to increase the slaughter yield. According to this, most recent pig breeds have less than $2 \%$ of intramuscular fat in meat with exception of Duroc breeds (Suzuki et al., 2003; Sheard et al., 2005; Alonso et al., 2009).

Literature is controversial if the percentage of meat intramuscular fat in affects several quality traits. With this purpose, the objective of this experiment was to evaluate the effect of intramuscular fat content on physical parameters and proximate composition in musculus longissimus dorsi (MLD) from Mangalitsa breed and their Slovak Large White x Mangalitsa crossbreed.

\section{Scientific hypothesis}

Created crossbreeds Slovak Large White and Mangalitsa will have fattening as well as production comparable to Slovak Large White, at which the qualitative traits of meat will be a prerequisite for the production of specific products based on fermentation, smoking and drying.

\section{MATERIAL AND METHODOLOGY}

\section{Biology material}

The experiment was implemented in the Experimental centre of animal at the Slovak University of Agriculture (SUA) in Nitra. Thirty-eight pigs were studied, and they were divided into two groups with different genotype: Mangalitsa breed $(\mathrm{n}=16)$ and Slovak Large White $x$ Mangalitsa crossbreed $(n=22)$.

\section{Feeding and rearing conditions}

Pigs of Mangalitsa breed were reared under intensive conditions. The pens were situated outdoor. The pen consisted of concrete floor and the straw was used as bedding. The Mangalitsa pigs were housed in groups of 4 . The pigs were fed by feed mixture (FM) for fatteners (Table 1 ), which received this feed mixture and drinking water by ad libitum system. The crossbreed Slovak Large White $\mathrm{x}$ Mangalitsa (SLW x Ma) were reared under intensive system in the indoor conditions. The size of pen was $3.10 \mathrm{~m} \mathrm{x} 1.07$ $\mathrm{m}$. The pen was divided into bedding area $\left(2.54 \mathrm{~m}^{2}\right)$ differenced by defecating area $\left(0.96 \mathrm{~m}^{2}\right)$. The floor in the bedding area consisted of agro-pavage and the floor in defecating area was composed of grate. The crossbreeds SLW x Ma received complete feed mixture applied at the different growth phases: until $35 \mathrm{~kg}$ OS-03, from $35 \mathrm{~kg}$ to $65 \mathrm{~kg}$ OS-04 and above the $65 \mathrm{~kg}$ OS-05. The composition of complete feed mixtures and nutrient content are presented on Table 1. The pigs received drinking water and feeding with ad libitum system.

\section{Sampling}

Pigs were slaughtered upon reaching $100 \mathrm{~kg}$ of live weight, so the fattening period lasted from $30 \mathrm{~kg}$ to $100 \mathrm{~kg}$ of live weight. Pigs were slaughtered in the slaughterhouse at the Experimental centre of Animals (SUA in Nitra). Firstly, the animals were electrically stunned by electric forceps during $4 \mathrm{~s}$ with voltage $250 \mathrm{~V}$ and the amperage 1.3. The stunned animal was hooked for Achilles tendon and then was killed by bleeding. The slaughtering was realized according to Government regulation (SR) no. 432/2012 of the coll. of Slovak Republic establishing the protection of animals during the slaughter. Samples of musculus longissimus dorsi (MLD) were dissected from the right-half carcasses. The MLD was taken at the level of the last thoracic vertebra. The dissection of carcasses was done performed according to standard practices of fatteningstatus and slaughter values in Slovakia.

Analysis of $\mathrm{pH}$, electric conductivity and drip loss

$\mathrm{pH}$ values $45 \mathrm{~min}\left(\mathrm{pH}_{45}\right)$ and $24 \mathrm{~h}\left(\mathrm{pH}_{24}\right)$ post mortem in MLD were measured by $\mathrm{pH}$ meter Hanna HI99161 in units $\log . \mathrm{molc}^{(\mathrm{H}+)}$. The electric conductivity was determined $45 \mathrm{~min}\left(\mathrm{EC}_{45}\right)$ and $24 \mathrm{~h}\left(\mathrm{EC}_{24}\right)$ post mortem by using an instrument Tecpro in unit $\mathrm{mS} . \mathrm{cm}^{-1}$. Drip loss in MLD was

Table 1 Composition of diet for pigs.

\begin{tabular}{lcccc}
\hline Traits & FM & OS03 & OS04 & OS05 \\
\hline Corn (\%) & 50 & 10 & 10 & 7 \\
Barley (\%) & 10 & 22 & 25 & 28 \\
Wheat (\%) & 10 & 44 & 42 & 49 \\
Wheat bran (\%) & 0 & 7 & 8 & 6 \\
Soybena meal (\%) & 10 & 13 & 12 & 7 \\
Sunflower seed (\%) & 10 & 0 & 0 & 0 \\
Granuled alfalfa (\%) & 7 & 0 & 0 & 0 \\
${ }^{1}$ Mineral and vitamin supplement (\%) & 3 & 3 & 3 & 3 \\
\hline
\end{tabular}

Note: ${ }^{1}$ retinol $200000 \mathrm{~m} . j .$, cholecalciferol $30000 \mathrm{~m} . j ., \alpha$-tocopherol $400 \mathrm{mg}$, riboflavin, $80 \mathrm{mg}$, pyridoxine $30 \mathrm{mg}$, cyanocobalamin $1000 \mathrm{mg}$, niacinamide $300 \mathrm{mg}$, folic acid $2 \mathrm{mg}$, pantothenic acid $300 \mathrm{mg}$, cholinchlorid $4000 \mathrm{mg}$, Cu 600 mg, Fe 3400 mg, Zn 1000 mg, Mn 1000 mg, I 30 mg, Se 8 mg.

Table 2 Nutrient composition of diets for pigs.

\begin{tabular}{lcccc}
\hline Traits & FM & OS03 & OS04 & OS05 \\
\hline Crude protein $(\mathrm{g})$ & 134 & 160 & 150 & 120 \\
Metabolisable energy (MJ) & 12.6 & 12.6 & 12.7 & 12.6 \\
Fibre (g) & 43 & 43 & 41 & 38 \\
Lysine (g) & 9.7 & 9.7 & 8.6 & 6.4 \\
\hline
\end{tabular}


measured $24 \mathrm{~h}$ post mortem by the method according to Honikel (1998).

\section{Instrumental colour and Warner-Bratzler shear force}

Meat colour was measured in MLD $24 \mathrm{~h}$ and 7 days post mortem by using spectrophotometer CM-2600d with CIE Lab space and illuminate D65 (Konica Minolta, Japan). Commission Internationale de l'Eclairage (1975) determined the following colour coordinates: L* (lightness, white \pm black), a* (redness, red \pm green) and $b^{*}$ (yellowness, yellow \pm blue). Values were recorded from the average of three random readings across each muscle surface. After 7 day - storage at temperature $4 \pm 1{ }^{\circ} \mathrm{C}$, the Warner-Bratzler shear force was analysed. The samples were heated to internal temperature of $71 \pm 1{ }^{\circ} \mathrm{C}$ for 30 minutes and subsequently chips in $1 \times 1 \mathrm{~cm}$ sheared across fibers. Warner-Bratzler shear force of meat was determined using a Warner-Bratzler shear device Chatillon (U.S.A), in accordance with Goodson et al. (2002). The shear of device was set up according to producer (capacity of tensometer was $5 \mathrm{~kg}$; speed was constant $0.005 \mathrm{~m} \cdot \mathrm{s}^{-1}$ ).

\section{Proximate composition}

The basic chemical parameters such as total water, total protein and intramuscular fat content were measured by the FT IR method (FourierTransform InfraTed) by using device Nicolet 6700 (Thermo Scientific, USA). FT IR is method of infrared spectroscopy. The homogenized sample is placed on the imagine opening of the integration sphere and absorbs infrared radiation. The final spectrum is shown molecular absorption and wavelength transmission (4000 $10000 \mathrm{~nm}$ ) using an interferogram, what is made as fingerprint of sample.

\section{Statistical analysis}

The effects of genotype on studied parameters were analysed by the analysis of variance (ANOVA) using the Statistic Analysis System (SAS) package: SAS 9.2 using of application Enterprise Guide 5.1. (SAS Institute Inc., 2012). Means and standard deviation $(S D)$ are presented in Tables. When ANOVA was significant the means were compared using Tukey's test. The correlation between intramuscular fat content in meat and physico-chemical parameters were analysed by calculation of Pearson's coefficient. The correlation between intramuscular fat content and protein content, cholesterol content as well as Warner-Bratzler shear force was expressed by linear regression.

\section{RESULTS AND DISCUSSION}

The results of physical and chemical parameters of MLD from genotypes are presented in Table 3 and Table 4 . The $\mathrm{pH} 45$ min and $24 \mathrm{~h}$ post mortem was not influenced by genotypes. The values of $\mathrm{pH}$ decreased after 24 hours post mortem, what agrees with studies of Lindahl et al. (2006) and Young, Bertram and Oksbjerg (2009). MLD of Mangalitsa pigs had slightly higher values of $\mathrm{pH} 45 \mathrm{~min}$ and $24 \mathrm{~h}$ post mortem than crossbreeds SLW x Ma. Similarly, Tomović et al. (2016) confirmed that MLD of Mangalitsa had higher values of $\mathrm{pH}$ compared to their crossbreed $\left(\mathrm{ph}_{45 \min } 6.37\right.$ vs. 6.26; $\mathrm{pH}_{24 \mathrm{~h}} 5.72$ vs. 5.53). Sirtori et al.
(2011) indicate that indigenous breed Cinta Senese had higher value of $\mathrm{pH}$ in MLD compared to crossbreed Italian Large White x Cinta Senese. The indigenous pig breed Chato Murciano had also higher value of $\mathrm{pH}$ in MLD than their crossbreed Chato Murciano $\mathrm{x}$ Iberian pig, what is obtained by Galián et al. (2007).

Electric conductivity (EC) 45 min post mortem was lower in MLD of Mangalitsa pigs compared to crossbreeds SLW $\mathrm{x}$ Ma. The EC increased after 24 hours post mortem, whereby Mangalitsa pigs had lower $\mathrm{EC}_{24}$ than crossbreeds SLW x Ma, Electric conductivity (EC) 45 min post mortem was lower in MLD of Mangalitsa pigs compared to crossbreeds SLW $x$ Ma. The EC increased after 24 hours post mortem, whereby Mangalitsa pigs had lower $\mathrm{EC}_{24}$ than crossbreeds SLW $\mathrm{x} \mathrm{Ma}$, indicating statistical significance $(p<0.05)$. In the same way, values of drip loss were lower in MLD of Mangalitsa in relation to crossbreeds SLW x Ma. Most commonly, $\mathrm{pH}$ and electrical conductivity are used as indicators for pale, soft, exudative (PSE) meat (Warriss et al., 1998; Josell, Von Seth and Tornberg, 2003; Altmann et al., 2005). Mörlein et al. (2007) applied strict levels for determination of PSE meat, when $\mathrm{pH}_{45}$ $<6.0-5.8$ are used as threshold levels. Then, $\mathrm{EC}_{24}$ values

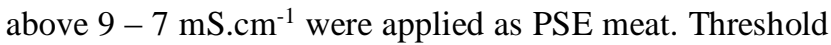
parameters for drip loss were above $7-9 \%$ within $48 \mathrm{~h}$ post mortem. On the basis of this fact, it was found in our study PSE of meat from Mangalitsa pigs fed by LFM. According to Lee et al. (2000) exist linear relationship between drip loss and electric conductivity, what is in consistent with our results. In our study was not determined pale, soft and exudative (PSE) meat. As regards Warner-Bratzler shear force (W-B), the MLD from Mangalitsa showed lower values of shear force $\left(2.63 \mathrm{~kg} . \mathrm{cm}^{-2}\right)$ compared to crossbreed SLW $\mathrm{x}$ Ma $\left(3.14 \mathrm{~kg} . \mathrm{cm}^{-2} ; p<0.05\right)$. The values were notably lower than those obtained by Stanišić et al. (2015) in Mangalitsa breed and Landrace as well as by Tomović et al. (2016) in MLD of Mangalitsa and Large White. Data confirmed that Mangalitsa has more tender meat than Landrace and Large White.

As regards the instrumental colour of MLD measured 45 min post mortem, the value CIE L* was higher in MLD from crossbreed SLW x Ma $(p<0.01)$ compared to MLD from Mangalitsa. Similarly, the value CIE $b^{*}$ was higher in MLD from crossbreed SLW x Ma $(p<0.01)$ and the value CIE a* was lower compared to MLD from Mangalitsa. However, no significant differences were found in CIE a* value due to genotype after $24 \mathrm{~h}$. The colour parameters (CIE L*, $\left.\mathrm{a}^{*}, \mathrm{~b}^{*}\right)$ in MLD increased after 7 days post mortem, which is common due to the maturation process of the meat. This fact agrees with studies of Estévez, Morcuende and Cava (2003), Lindahl et al. (2006) and Stanišić et al. (2016). The CIE L* and CIE a* values were significantly influenced by genotype where Mangalitsa exhibited darker (CIE L*; $p<0.001$ ) and redder (CIE a*; $p$ <0.05) MLD compared to crossbreed SLW x Ma. Although were not found significant differences for CIE $b^{*}$ in MLD, Mangalitsa had lower values than crossbreed SLW $\mathrm{x}$ Ma. It is in accordance with Stanišić et al. (2016). 
Table 3 Physical parameters of musculus longissimus dorsi.

\begin{tabular}{|c|c|c|c|}
\hline Parameters & $\begin{array}{c}\text { Mangalitsa }(n=16) \\
\text { Mean } \pm S D\end{array}$ & $\begin{array}{l}\text { SLW x Ma }(n=22) \\
\text { Mean } \pm S D\end{array}$ & $p<$ value \\
\hline $\mathrm{pH}_{45 \min }\left(\log \cdot \mathrm{molc}^{(\mathrm{H}+)}\right)$ & $6.09 \pm 0.27$ & $6.02 \pm 0.19$ & 0.425 \\
\hline $\mathrm{pH}_{24 \text { hours }}\left(\log \cdot \mathrm{molc}^{(\mathrm{H}+)}\right)$ & $5.69 \pm 0.07$ & $5.68 \pm 0.11$ & 0.850 \\
\hline $\mathrm{EC}_{45 \min }\left(\mathrm{mS} . \mathrm{cm}^{-1}\right)$ & $3.31 \pm 1.27$ & $3.92 \pm 0.47$ & 0.284 \\
\hline $\mathrm{EC}_{24 \text { hours }}\left(\mathrm{mS} . \mathrm{cm}^{-1}\right)$ & $9.31 \pm 1.91$ & $10.86 \pm 2.25$ & 0.019 \\
\hline Drip loss24hours $(\%)$ & $7.15 \pm 2.99$ & $8.22 \pm 2.78$ & 0.262 \\
\hline Colour $_{24 \text { hours }}$ CIE L* & $53.06 \pm 4.34$ & $58.12 \pm 4.93$ & 0.002 \\
\hline Colour $_{24 \text { hours }}$ CIE a* & $3.21 \pm 1.36$ & $2.50 \pm 1.51$ & 0.139 \\
\hline Colour $_{24 h o u r s ~}$ CIE b* & $10.41 \pm 1.53$ & $11.89 \pm 1.45$ & 0.005 \\
\hline Colour $_{7 \text { days }}$ CIE L* & $54.51 \pm 4.67$ & $60.46 \pm 4.58$ & 0.001 \\
\hline Colour $_{\text {days }}$ CIE a* & $6.67 \pm 2.98$ & $5.03 \pm 2.01$ & 0.044 \\
\hline Colour $_{7 \text { days }}$ CIE b* & $13.14 \pm 2.56$ & $14.04 \pm 1.92$ & 0.228 \\
\hline Warner-Brazler shear force $\left(\mathrm{kg} . \mathrm{cm}^{-2}\right)$ & $2.63 \pm 0.75$ & $3.14 \pm 0.65$ & 0.031 \\
\hline
\end{tabular}

Note: SW: slaughter weight, SLW x Ma: crossbreeds Slovak Large White x Mangalitsa, SEM: Standard error of mean.

Comparing our results with those obtained by Franci et al. (2005), we found that their results for CIE L* and CIE $b^{*}$ were lower, but CIE a* value was higher. In their study pure breed Cinta Senese exhibited darker (CIE L*) and redder (CIE $\left.a^{*}\right)$ meat, but lower value of index $b^{*}$ compared to crossbreed Large White x Cinta Senese. Similarly, Szulc et al. (2012) obtained that pure breed Zlotnicka spotted had higher values of CIE L*, CIE a* as well as CIE b* compared to crossbreed Zlotnicka spotted x Polish Large White. On the contrary Poto, Galián and Peinado (2007) worked with Spanish indigenous breed Chato Murciano and they found lower values of colour parameters in MLD from crossbreed Chato Murciano x Large White than in indigenous breed Chato Murciano. On the other hand, Renaudeau and Mourot (2007) studied differences on meat quality between indigenous pigs Creole and Large White, where Creole pigs had lower colour parameters in relation to Large White. Bednářová et al. (2014) analyzed samples of pork 72 hours post mortem from different supliers. $\mathrm{L}^{*}$ value from $m$. semimenbranosus was found from 46.13 to 48.53

Regarding the proximate parameters, water content was significantly higher in MLD from Mangalitsa than in MLD from crossbreed SLW x Ma $(p<0.05)$. The MLD from Mangalitsa had lower protein content $(p<0.05)$, but higher percentage of intramuscular fat than MLD from crossbreed SLW x Ma, where the difference did not reach the significance. Franci et al. (2005) observed that pure breed Cinta Senese had lower water content as well as protein content compared to their crossbreed Large White $\mathrm{x}$ Cinta Senese and the percentage of intramuscular fat was higher. Data are in accordance with our results except to water content in MLD. Our results showed higher values of water content and protein content, but lower percentage of intramuscular fat than in study of Sirtori et al. (2011) and Parunović et al. (2013). In their study, the indigenous breeds such as Cinta Senese, compared to Mangalitsa, had lower percentage of water as well as protein content and higher percentage of intramuscular fat in meat compared to commercial breeds. According to Serra et al. (1998), the pure breed Iberian had lower water and protein content, while the percentage of intramuscular fat was higher than Landrace pig meat. The results of cholesterol content were in accordance with percentage of intramuscular fat content in MLD, however no significant differences were found due to genotype. As regards the cholesterol content, Pârvu et al. (2012) determined, that Large White pig meat had higher cholesterol content with lower percentage of intramuscular fat (cholesterol content $41.64 \mathrm{mg}^{100 \mathrm{~g}^{-1}}$; IMF 23.21\%) compared to Mangalitsa (cholesterol content 61.24 mg. $100 \mathrm{~g}^{-1}$; IMF $10.69 \%$ ). These results are in contrast with ours. The cholesterol content of MLD was in the study of Parunović et al. (2013) and Parunović et al. (2015) higher than in our results, but they confirmed that Mangalitsa had higher value of cholesterol compared to Swedish Landrace pig meat. Similarly, Salvatori et al. (2008) found that indigenous pigs Casertana had higher cholesterol content in MLD than their crossbreeds Casertana x Large White. On the other hand, Stajić et al. (2011) indicated that Mangalitsa had lower cholesterol content in meat in relation to Landrace. Although it is saying that Mangalitsa pigs had lower cholesterol content in the meat, it can be confirmed by our study that Mangalitsa had higher cholesterol content than their crossbreeds.

Table 5 shows coefficients of Pearson's correlation between physico-chemical parameters and intramuscular fat content in musculus longissimus dorsi. The percentage of intramuscular fat (IMF) in MLD was positively correlated ( $p$ <0.05) with CIE $a^{*} 7$ days post mortem $(r=0.324)$ and also with cholesterol content $(r=0.656$; $p<0.001)$. The relationship between percentage of intramuscular fat and cholesterol content in meat is shown by Figure 1 . In contrast, the IMF in MLD was negatively correlated with percentage of water $(r=0.399 ; p<0.05)$ and with protein content in MLD $(r=-0.812 ; p<0.001)$. These results are in accordance with study of Vranic et al. (2015) and Tomović et al. (2016). Figure 2 represents the relationship between intramuscular fat content and protein content in meat by linear regression. As regarding the Warner-Bratzler shear force, no significance was found between intramuscular fat and tenderness of meat. The results are in accordance with Jeong et al. (2010). On the contrary, Barlocco et al. (2006) found positive correlation between Warner-Bratzler shear force and intramuscular fat content in the meat. In other parameters, no significant correlations were found. 
Table 4 Chemical parameters of musculus longissimus dorsi.

\begin{tabular}{lccccc}
\hline \multirow{2}{*}{ Parameters } & \multicolumn{2}{c}{ Mangalitsa $(\mathbf{n}=\mathbf{1 6})$} & \multicolumn{2}{c}{ SLW $\mathbf{x}$ Ma $(\mathbf{n}=\mathbf{2 2})$} & \multirow{2}{*}{$\boldsymbol{p}<$ value } \\
\cline { 2 - 5 } & Mean & SD & Mean & SD & 0.017 \\
Total water (\%) & 73.53 & 0.61 & 73.01 & 0.58 & 0.019 \\
Total protein (\%) & 24.15 & 0.66 & 24.56 & 0.34 & 0.286 \\
Intramuscular fat (\%) & 1.93 & 0.91 & 1.66 & 0.59 & 0.203 \\
Cholesterol (mg.100g $\left.{ }^{-1}\right)$ & 43.01 & 7.16 & 38.91 & 10.41 & \\
\hline
\end{tabular}

Note: SW: slaughter weight, SLW x Ma: crossbreeds Slovak Large White x Mangalitsa, SD: standard deviation.

Table 5 Pearson's correlation coefficient between physico-chemical parameters and intramuscular fat content in musculus longissimus dorsi of the pigs.

\begin{tabular}{|c|c|}
\hline Parameters & IMF \\
\hline $\mathrm{pH}_{45 \min }$ & 0.071 \\
\hline $\mathrm{pH}_{24 \text { hours }}$ & -0.186 \\
\hline $\mathrm{EC}_{45 \mathrm{~min}}$ & -0.134 \\
\hline $\mathrm{EC}_{24 \text { hours }}$ & -0.161 \\
\hline Drip loss 24 hours & -0.221 \\
\hline Colour $_{24 \text { hours }}$ CIE L* & -0.046 \\
\hline Colour $_{24 \text { hours }}$ CIE a* & 0.126 \\
\hline Colour $_{24 \text { hours }}$ CIE b* & 0.044 \\
\hline Colour $_{7 \text { days }}$ CIE L* & -0.082 \\
\hline Colour $_{7 \text { days }}$ CIE a* & $0.324^{*}$ \\
\hline Colour $_{7 \text { days }}$ CIE b* & 0.134 \\
\hline Warner-Brazler shear force & -0.153 \\
\hline Total water & $-0.399^{*}$ \\
\hline Total protein & $-0.812^{* * *}$ \\
\hline Cholesterol & $0.656^{* * *}$ \\
\hline
\end{tabular}

Note: IMF: intramuscular fat content, ***: $p<0.001, *: p<0.05$

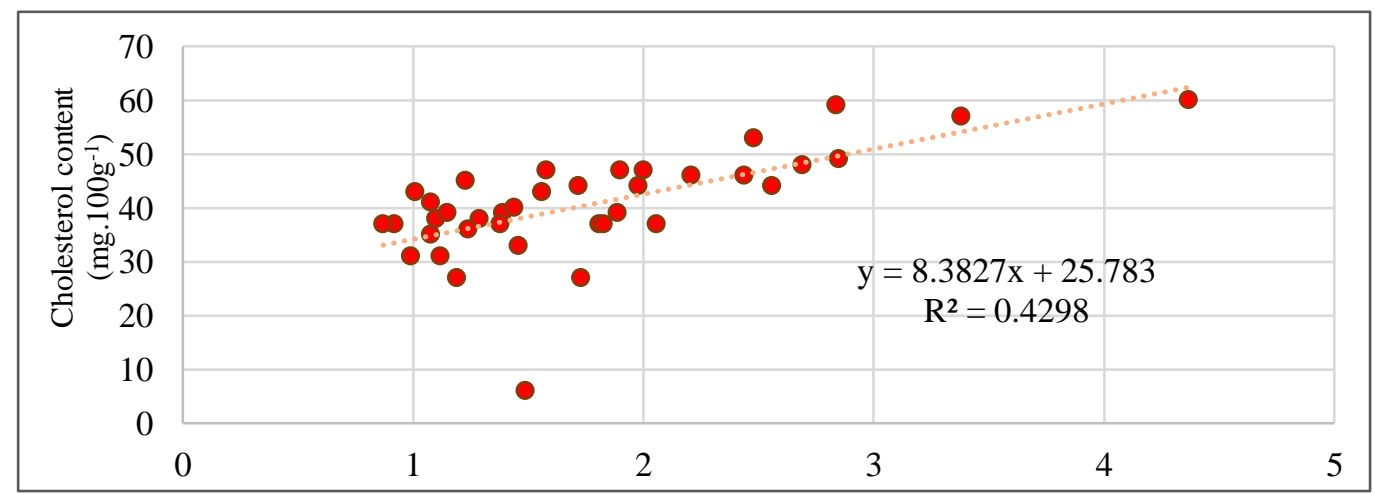

Figure 1 Intramuscular fat content in meat in relation to cholesterol content (\%).

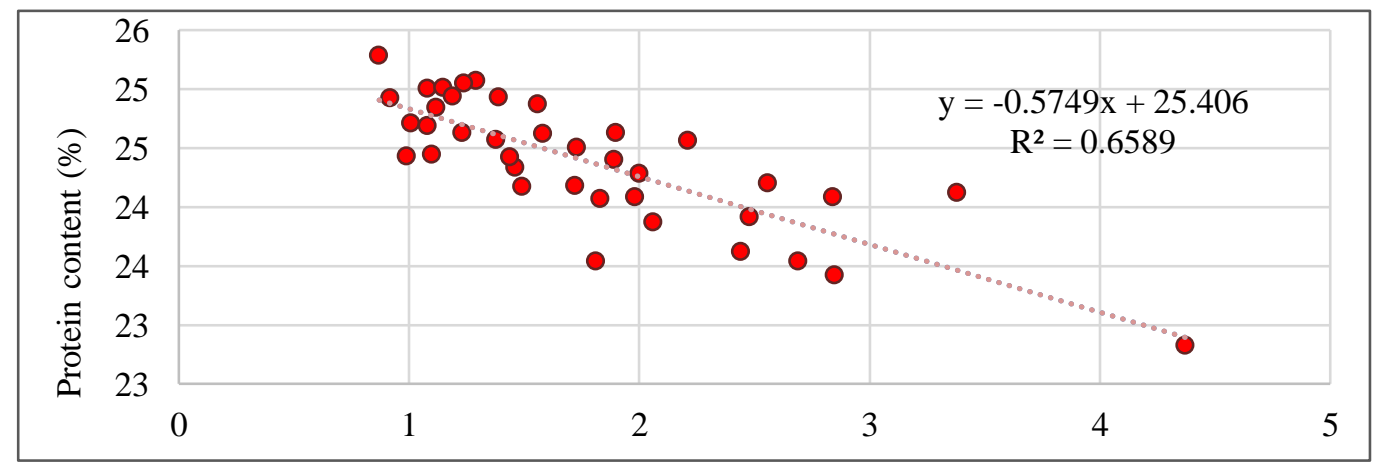

Figure 2 Intramuscular fat content in meat in relation to protein content (\%). 


\section{CONCLUSION}

Chemical analysis showed that MLD from Mangalitsa had lower protein content $(24.15$, resp. $24.56 \%)$ and higher content of intramuscular fat (1.93, resp. 1.66\%) compared to Slovak Large White x Mangalitsa crossbreed. As regards the Warner-Bratzler shear force, the meat from Mangalitsa was tenderer than in crossbreeds $(p<0.05)$. Intramuscular fat in the meat positively correlated with colour parameter CIE a* $(\mathrm{r}=0.324 ; p<0.05)$ as well as cholesterol content $(\mathrm{r}$ $=0.656 ; p<0.001)$. Cholesterol content was found statistically non-significant difference (Mangalitsa 43.01 and SLW x Ma $38.91 \mathrm{mg} .100 \mathrm{~g}^{-1}$ ).

It can be concluded that the percentage of intramuscular fat significantly influenced the physical and the chemical parameters of pork. As regards the differences between genotypes, Mangalitsa has darker, redder and tenderer meat with lower moisture content and higher intramuscular fat content compared to crossbreeds Slovak Large White $\mathrm{x}$ Mangalitsa. The meat from Mangalitsa is more suitable for production of special meat products (fermented and smoked).

\section{REFERENCES}

Alonso, V., del Mar Campo, M., Español, S., Roncalés, P., Beltrán, J. A. 2009. Effect of crossbreeding and gender on meat quality and fatty acid composition in pork. Meat Science, vol. 81, no. $1, \quad$ p. 209-217. https://doi.org/10.1016/j.meatsci.2008.07.021

Alonso, V., Muela, E., Gutiérrez, B., Calanche, J. B., Roncalés, P., Beltrán, J. A. 2015. The inclusion of Duroc breed in maternal line affects pork quality and fatty acid profile. Meat $\begin{array}{lllll}\text { Science, } & \text { vol. } & 107, & \text { p. } & 49-56 .\end{array}$ https://doi.org/10.1016/j.meatsci.2015.04.011

Altmann, M., Kirchheim, U., Schöberlein, L., Wähner, M., Wicke, M., Fischer, K. 2005. Incidence of PSE condition in market hogs-Monitoring results for various abattoirs in Germany. Fleischwirtschaft, vol. 85, no. 7, p. 101-104.

Barlocco, N., Vadell, A., Ballesteros, F., Galietta, G., Cozzolino, D. 2006. Predicting intramuscular fat, moisture and Warner-Bratzler shear force in pork muscle using near infrared reflectance spectroscopy. Animal Science, vol. 82, no. 1, p. 111-116. https://doi.org/10.1079/ASC20055

Bednářová, M., Kameník, J., Sláková, A., Pavlík, Z., Tremlová, B. 2014. Monitoring of color and $\mathrm{pH}$ in muscles of pork leg ( $m$. adductor and $m$. semimembranosus). Potravinarstvo, vol. 8, no. 1, p. 48-53. https://doi.org/10.5219/337

Comission Internationale de l'Eclairage (1975): Comission Internationale de l'Eclairage $18^{\text {th }}$ Session, London, UK, September 1975, C.I.E. publication, $36 \mathrm{p}$.

Egerszegi, I., Rátky, J., Solti, L., Brüssow, K. P. 2003. Mangalica - an indigenous swine breed from Hungary (Review). Archives Animal Breeding, vol. 46, p. 245-256. https://doi.org./10.5194/aab-46-245-2003

Estévez, M., Morcuende, D., Cava, R. 2003. Oxidative and colour changes in meat from three lines of free-range reared Iberian pigs slaughtered at $90 \mathrm{~kg}$ live weight and from industrial pig during refrigerated storage. Meat Science, vol. 65, no. 3, p. 1139-1146. https://doi.org/10.1016/S03091740(02)00343-1

Franci, O., Bozzi, R., Pugliese, C., Acciaioli, A., Campodoni, G., Gandini, G. 2005. Performance of Cinta Senese pigs and their crosses with Large White. 1. Muscle and subcutaneous fat characteristics. Meat Science, vol. 69, no. 3, p. 545-550. https://doi.org/10.1016/j.meatsci.2004.10.005
Galián, M., Peinado, B., Martínez, C., Periago, M. J., Ros, G., Poto, A. 2007. Comparative study of the characteristics of the carcass and the meat of the Chato Murciano pig and its cross with Iberian pig, reared indoors. Animal Science Journal, vol. 78 , p. 659-667. https://doi.org/10.1111/j.17400929.2007.00487.x

Goodson, K. J., Morgan, W. W., Reagan, J. O., Gwartney, B. L., Couringtion, S. M., Wise, J. W., Savell, J. W. 2002. Beef customer satisfaction: factors affecting consumer evaluations of clod steaks. Journal of Animal Science, vol. 80, no. 2, p. 401408. https://doi.org/10.2527/2002.802401x

Government regulation (SR) no. 432/2012 of the coll. of Slovak Republic of 12 December 2012 establishing the protection of animals during the slaughter, p. 3248-3257.

Hamill, R. M., McBryan, J., McGee, C., Mullen, A. M., Sweeney, T., Talbot, A., Cairns, M. T., Davey, G. C. 2012. Functional analysis of muscle gene expression profiles associated with tenderness and intramuscular fat content in pork. Meat Science, vol. 92, no. 4, p. 440-450. https://doi.org/10.1016/j.meatsci.2012.05.007

Honikel, K. O. 1998. Reference methods for the assessment of physical characteristics of meat. Meat Science, vol. 49, no. 4, p. 447-457. https://doi.org/10.1016/S0309-1740(98)00034$\underline{5}$

Jeong, D. W., Choi, Y. M., Lee, S. H., Choe, J. H., Hong, K. C., Park, H. C., Kim, B. C. 2010. Correlations of trained panel sensory values of cooked pork with fatty acid composition, muscle fiber type, and pork quality characteristics in Berkshire pigs. Meat Science, vol. 86, no. 3, p. 607-615. https://doi.org/10.1016/j.meatsci.2010.04.011

Josell, A., Von Seth, G., Tornberg, E. 2003. Sensory quality and the incidence of PSE of pork in relation to crossbreed and RN phenotype. Meat Science, vol. 65, no. 1, p. 651-660. https://doi.org/10.1016/S0309-1740(02)00268-1

Lee, S., Norman, J. M., Gunasekaran, S., Van Laack, R. L. J. M., Kim, B. C., Kauffman, R. G. 2000. Use of electrical conductivity to predict water-holding capacity in post-rigor pork. Meat Science, vol. 55, no. 4, p. 385-389. https://doi.org/10.1016/S0309-1740(99)00166-7

Lindahl, G., Henckel, P., Karlsson, A. H., Andersen, H. J. 2006. Significance of early post mortem temperature and $\mathrm{pH}$ decline on colour characteristics of pork loin from different crossbreeds. Meat Science, vol. 72, no. 4, p. 613-623. https://doi.org/10.1016/j.meatsci.2005.09.014

Mörlein, D., Link, G., Werner, C., Wicke, M. 2007. Suitability of three commercially produced pig breeds in Germany for a meat quality program with emphasis on drip loss and eating quality. Meat Science, vol. 77, no. 4, p. 504511. https://doi.org/10.1016/j.meatsci.2007.04.030

Parunović, N., Petrovic, M., Matekalo-Sverak, V., Radovic, Č., Stanišić, N. 2013. Carcass properties, chemical content and fatty acid composition of the musculus longissimus of different pig genotypes. South African Journal of Animal Science, vol. 43, no. 2, p. 12-136. https://doi.org/10.4314/sajas.v43i2.2

Parunović, N., Petrovic, M., Djordjevic, V., Petronijevic, R., Lakicevic, B., Petrovic, Z., Savic, R. 2015. Cholesterol content and fatty acids composition of Mangalitsa pork meat. Procedia Food Science, vol. 5, p. 215-218. https://doi.org/10.1016/j.profoo.2015.09.021

Pârvu, M., Bogdan, T. A., Andronie, C. I., Simion, E. V., Amfim, A. 2012. Influence of Cold Stress on the Chemical Composition of Carcass to Mangalica pigs. Scientific Papers: Animal Science and Biotechnologies, vol. 45, no. 2, p. 394-396.

Poto, A., Galián, M., Peinado, B. 2007. Chato Murciano pig and its crosses with Iberian and Large White pigs, reared outdoors. Comparative study of the carcass and meat 
characteristics. Livestock Science, vol. 111, no. 1-2, p. 96-103. https://doi.org/10.1016/j.livsci.2006.12.005

Pugliese, C., Sirtori, F. 2012. Quality of meat and meat products produced from southern European pig breeds. Meat Science, vol. 90, no. 3, p. 511-518. https://doi.org/10.1016/j.meatsci.2011.09.019

Renaudeau, D., Mourot, J. 2007. A comparison of carcass and meat quality characteristics of Creole and Large White pigs slaughtered at $90 \mathrm{~kg} \mathrm{BW.} \mathrm{Meat} \mathrm{Science,} \mathrm{vol.} \mathrm{76,} \mathrm{no.} \mathrm{1,} \mathrm{p.} \mathrm{165-}$ 171. https://doi.org/10.1016/j.meatsci.2006.10.024

SAS Institute Inc. 2012. SAS® 9.2. Cary, NC, USA : SAS Institute Inc, $384 \mathrm{p}$.

Salvatori, G., Filetti, F., Cesare, C., Maiorano, G., Pilla, F., Oriani, G. 2008. Lipid composition of meat and backfat from Casertana purebred and crossbred pigs reared outdoors. Meat Science, vol. 80, no. 3, p. 623-631. https://doi.org/10.1016/j.meatsci.2008.02.013

Serra, X., Gil, F., Pérez-Enciso, M., Oliver, M. A., Vázquez, J. M., Gispert, M., Díaz, I., Moreno, F., Latorre, R., Noguera, J. L. 1998. A comparison of carcass, meat quality and histochemical characteristics of Iberian (Guadyerbas line) and Landrace pigs. Livestock Production Science, vol. 56, p. 215223. https://doi.org/10.1016/S0301-6226(98)00151-1

Sheard, P. R., Nute, G. R., Richardson, R. I., Wood, J. D. 2005. Effects of breed and marination on the sensory attribute of pork from Large White and Hampshire-sired pigs. Meat Science, vol. 70, no. 4, p. 699-707. https://doi.org/10.1016/j.meatsci.2005.03.006

Sirtori, F., Crovetti, A., Zilio, D. M., Pugliese, C., Acciaoli, A., Campodoni, G., Bozzi, R., Franci, O. 2011. Effect of sire breed and rearing system on growth, carcass composition and meat traits of Cinta Senese crossbred pigs. Italian Journal of Animal Science, vol. 10, no. 4, p. 188-194. https://doi.org/10.4081/ijas.2011.e47

Stajić, S., Živković, D., Perunović, M., Šobajić, S., Vranić, D. 2011. Cholesterol content and atherogenicity of fermented sausages made of pork meat from various breeds. Proceida Food Science: $11^{\text {th }}$ International Congress on Engineering and Food (ICEF11), vol. 1, p. 568-575. https://doi.org/10.1016/j.profoo.2011.09.086

Stanišić, N., Petrovic, M., Radovic, C., Gogić, M., Parunović, N., Stajić, S., Petricevic, M. 2013. The effect of gender and breed on some properties of pig meat. Biotechnology in Animal Husbandry, vol. 29, p. 651-658. https://doi.org/10.2298/BAH1304651S

Stanišić, N., Radović, Č., Stajić, S., Živković, D., Tomašević, I. 2015. Physicochemical properties of meat from Mangalitsa pig breed. Meso, vol. 17, no. 1, p. 50-53.

Stanišić, N., Parunović, N., Stajíć, S., Petrović, M., Radović, Č., Živković, D., Petričević, M. 2016. Differences in meat colour between free-range Swallow Belly Mangalitsa and commercially reared Swedish Landrace pigs during 6 days of vacuum storage. Archives Animal Breeding, vol. 59, p. 159166. https://doi.org/10.5194/aab-59-159-2016

Straadt, I. K., Aaslyng, M. D., Bertram, H. CH. 2013. Sensory and consumer evaluation of pork loins from crossbreeds between Danish Landrace, Yorkshire, Duroc, Iberian and Mangalitza. Meat Science, vol. 95, no. 1, p. 27-35. https://doi.org/10.1016/j.meatsci.2013.04.026

Suzuki, K., Shibata, T., Kadowaki, H., Abe, H., Toyoshima, T. 2003. Meat quality comparison of Berkshire, Duroc and rossbred pigs sired by Berkshire and Duroc. Meat Science, vol. 64, no. 1, p. 35-42. https://doi.org/10.1016/S03091740(02)00134-1

Szulc, K., Lisiak, D., Grzeoekowiak, E., Nowaczewski, S. 2012. The influence of cross-breeding Zlotnicka Spotted native breed sows with boars of Duroc (D) and Polish Large White (PLW) breeds on meat quality. African Journal of Biotechnology, vol. 11, no. 19, p. 4471-4477. https://doi.org/10.5897/AJB11.3504

Tomović, V. M., Šević, R., Jokanović, M., Šojić, B., Škaljac, S., Tasić, T., Ikonić, P., Polak, M. L., Polak, T., Demšar, L. 2016. Quality traits of longissimus lumborum muscle from White Mangalica, Duroc x White Mangalica and Large White pigs reared under intensive conditions and slaughtered at 150 kg live weight: a comparative study. Archives Animal Breeding, vol. 59, p. 401-415. https://doi.org/10.5194/aab-59$\underline{401-2016}$

Vranic, D., Nikolic, D., Koricanac, V., Stanisic, N., Lilic, S., Djinovic-Stojanovic, J., Parunovic, N. 2015. Chemical composition and cholesterol content in M. longissimus dorsi from free-range reared Swallow-belly Mangalitsa: the effect of gender. Procedia Food Science, vol. 5, p. 316-319. https://doi.org/10.1016/j.profoo.2015.09.066

Warriss, P. D., Brown, S. N., Gade, P. B., Santos, C., Costa, L. N., Lambooij, E., Geers, R. 1998. An analysis of data relating to pig carcass quality and indices of stress collected in the European Union. Meat Science, vol. 49, no. 2, p. 137-144. https://doi.org/10.1016/S0309-1740(97)00133-2

Young, J. F., Bertram, H. C., Oksbjerg, N. 2009. Rest before slaughter ameliorates pre-slaughter stress-induced increased drip loss but not stress-induced increase in the toughness of pork. Meat Science, vol. 83, no. 4, p. 634-341. https://doi.org/10.1016/j.meatsci.2009.07.019

\section{Acknowledgments:}

This study was supported by project - Agency of Ministry of Education, Science, Research and Sport of the Slovak Republic: VEGA 1/0364/15 and KEGA 015SPU-4/2019.

\section{Contact address:}

Petra Lípová, Slovak University of Agriculture, Faculty of Agrobiology and Food Resources, Department of Animal Husbandry, Tr. A. Hlinku 2, 94976 Nitra, Slovakia, Tel.: +421376414414,

E-mail: petalipova@gmail.com

ORCID: https://orcid.org/0000-0002-5840-2382

Ondrej Debrecéni, Slovak University of Agriculture, Faculty of Agrobiology and Food Resources, Department of Animal Husbandry, Tr. A. Hlinku 2, 94976 Nitra, Slovakia, Tel: +421376414805,

E-mail: ondrej.debreceni@ uniag.sk

ORCID: https://orcid.org/0000-0003-3241-1800

Ondřej Bučko, Slovak University of Agriculture, Faculty of Agrobiology and Food Resources, Department of Animal Husbandry, Tr. A. Hlinku 2, 94976 Nitra, Slovakia, Tel: +421376414802,

E-mail: ondrej.bucko@ gmail.com ORCID: https://orcid.org/0000-0001-6942-511X

*Klára Vavrišínová, Slovak University of Agriculture, Faculty of Agrobiology and Food Resources, Department of Animal Husbandry, Tr. A. Hlinku 2, 94976 Nitra, Slovakia, Tel: +421376414800,

E-mail: klara.vavrisinova@uniag.sk

ORCID: https://orcid.org/0000-0002-1042-4830

Corresponding author: $*$ 